Institute of $\mathbf{F}_{\text {ood and }} \mathbf{A}$ gricultural $\mathbf{S}_{\text {ciences }}$

\title{
Huntsman Spider, Heteropoda venatoria (Linnaeus) (Arachnida: Araneae: Sparassidae) ${ }^{1}$
}

G. B. Edwards, Jr. ${ }^{2}$

\section{Introduction}

The huntsman spider, Heteropoda venatoria (L.), sometimes called the giant crab spider or the banana spider (due to its occasional appearance in marketed bananas), is a cosmotropical species introduced into and now occurring in the U.S., in subtropical areas of Florida, Texas, and California. It is presumed to have been introduced from Asia, where many of its closest relatives live (Gertsch 1948). It has sometimes been mistaken for a large brown recluse (Loxosceles reclusa Gertsch and Mulaik, family Loxoscelidae), a poisonous spider, but it is neither related nor is it dangerous. Some authors place this spider in the family Heteropodidae, due to the uncertainty of the name Sparassidae (Platnick and Levi 1973).

\section{Abbreviated Synonymy}

Aranea venatoria Linnaeus 1767

Aranea regia Fabricius 1793

Heteropoda venatoria, Latreille 1804

Thomisus leucosia Walckenaer 1805

Micrommata setulosa Perty 1833

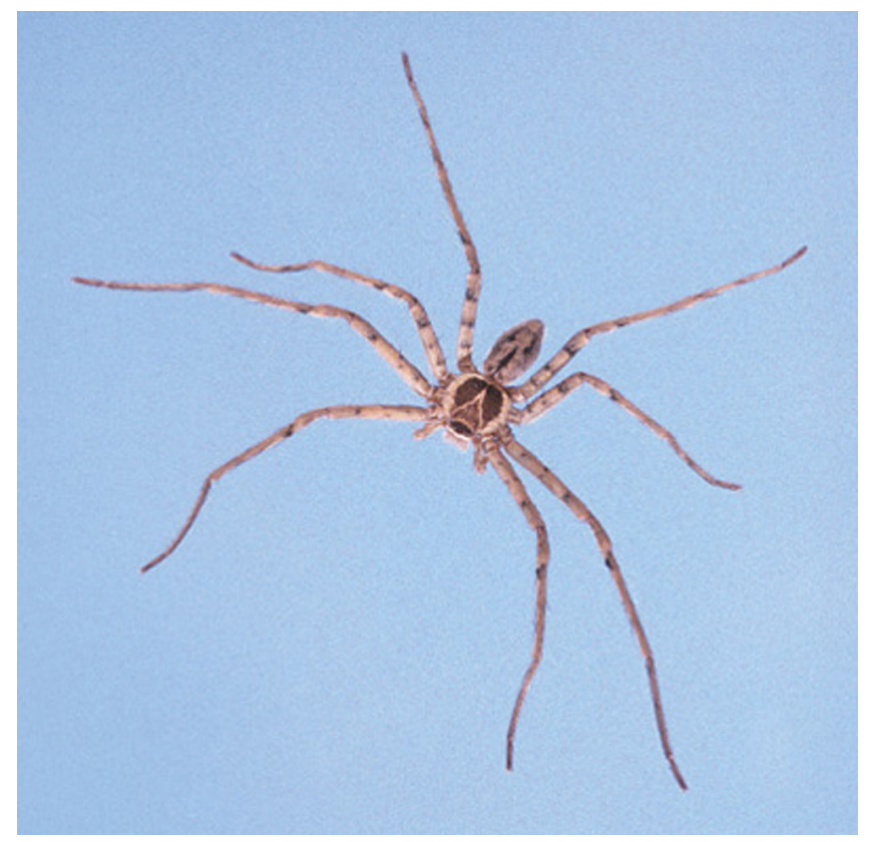

Figure 1. Dorsal view of male huntsman (giant crab) spider, Heteropoda venatoria (Linnaeus). Credits: Jeffrey Lotz, Division of Plant Industry

\section{Description}

Heteropoda venatoria is a large brown spider with a flattened body structure and very little dorsal pattern. Adult specimens have a body length of 2.2 to

1. This document is EENY-160 (originally published as DPI Entomology Circular 205), one of a series of Featured Creatures from the Entomology and Nematology Department, Florida Cooperative Extension Service, Institute of Food and Agricultural Sciences, University of Florida. Published: October 2000. Revised: July 2003. This document is also available on Featured Creatures Website at http://creatures.ifas.ufl.edu. Please visit the EDIS Website at http://edis.ifas.ufl.edu. Additional information on these organisms, including many color photographs, is available at the Entomology and Nematology Department website at http://entnemdept.ifas.ufl.edu/.

2. G. B. Edwards, Jr., Florida Department of Agriculture and Consumer Services, Division of Plant Industry, Gainesville, FL.

The Institute of Food and Agricultural Sciences is an equal opportunity/affirmative action employer authorized to provide research, educational information and other services only to individuals and institutions that function without regard to race, color, sex, age, handicap, or national origin. For information on obtaining other extension publications, contact your county Cooperative Extension Service office. Florida Cooperative Extension Service/Institute of Food and Agricultural Sciences/University of Florida/Christine Taylor Waddill, Dean. 


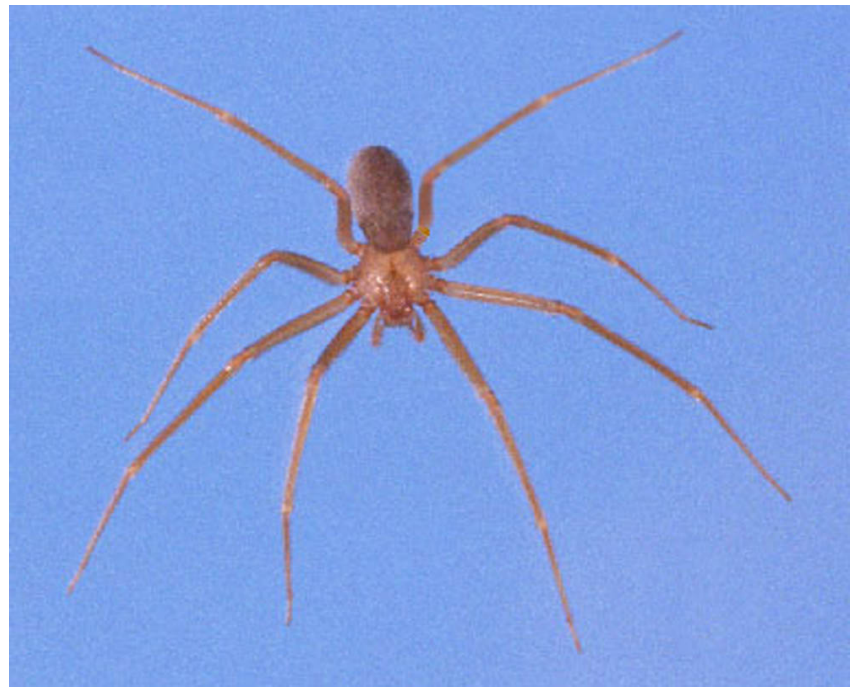

Figure 2. Female brown recluse spider, Loxosceles reclusa Gertsch and Mulaik, dorsal view for comparison with dorsal view of male huntsman spider, Heteropoda venatoria (Linnaeus). Credits: Jeffrey Lotz, Division of Plant Industry

$2.8 \mathrm{~cm}$ (about 1 inch), and have a leg span of 7 to 12 $\mathrm{cm}$ (3 to 5 inches). Adult females have a larger body size, especially the abdomen, than males. Adult males have longer legs than females, and the long male palpi have the terminal segment enlarged and the ventral sclerites exposed, as in most true spiders. Both sexes have a yellow to cream clypeus and a wide marginal band encircling the rest of the carapace, tan in females and cream in males. In addition, males have a dark, longitudinal stripe on the abdomen and a light-bordered pale area behind the eyes. The legs of both sexes have distinct black spots from each of which arises an erectile macroseta. Otherwise, the spider is not conspicuously hairy.

\section{Habits and Habitat}

Females of $H$. venatoria make flattened, disc-like eggsacs about $1.5 \mathrm{~cm}$ in diameter which contain over 200 eggs. The eggsac is carried under the body, its size and shape probably causing the female to remain relatively immotile. All stages of development of juveniles and adults appear to occur simultaneously throughout the year.

This and similar species are highly valued in tropical countries because they capture and feed on cockroaches and other domestic insect pests. As with other vagrant spiders, huntsman spiders do not use webs to capture prey. Their great speed and strong chelicerae (mouthparts) are used to capture the insects on which they feed. Poison is also injected into the prey from glands extending from the chelicerae into the cephalothorax.

The flattened body enables this large spider to fit into surprisingly small cracks and crevices. This ability, along with its adaptability to human habitations, helps explain its frequent occurrence in houses, barns, sheds, under boards on the ground, and in other sheltered areas. Being cold-sensitive, these spiders cannot exist outdoors in areas with freezing winter temperatures; occasionally they occur in greenhouses and other heated buildings in temperate climates. On the other hand, in southern Florida where frost is rare, these spiders have become "wild" (i.e., no longer requiring man-made structures). In the Homestead area, H. venatoria is now established in the "wild" and is common in avocado groves (Whitcomb unpublished). They can be easily collected at night by using a headlight (Wallace 1937) as their eyes reflect light, appearing as blue spots on the trunks of trees and on the ground, much like wolf spiders.

\section{Survey and Detection}

In Florida, $H$. venatoria may be distinguished from other large, cursorial spiders by its flattened brown body and the black spots around the macrosetae on the legs. In warm weather, it may be found in and about human habitations; in cold weather it will be found indoors, under furniture or cabinets, behind wall hangings, and in closets and garages. It is not a dangerous spider, but a locally painful bite can be delivered to any human who carelessly handles a huntsman spider.

\section{Selected References}

- Gertsch WJ. 1948. American spiders. D. Van Nostrand Co., Inc., New York. 284 p.

- Platnick NI, Levi HW. 1974. On names of spiders. British Arach. Soc. Bull. 2: 166-167.

- Wallace HK. 1937. The use of a headlight in collecting nocturnal spiders. Ent. News 48: $160-161$. 